Article

\title{
Amperometric Sensor for Detection of Chloride Ions ${ }^{\dagger}$
}

${ }^{\dagger}$ Dedicated to the UNESCO International Year of Planet Earth

\section{Libuse Trnkova ${ }^{1}$, Vojtech Adam ${ }^{2,3}$, Jaromir Hubalek ${ }^{4}$, Petr Babula ${ }^{5}$ and Rene Kizek ${ }^{1, *}$}

1 Department of Chemistry, Faculty of Science, Masaryk University, Kotlarska 2, CZ-611 37 Brno, Czech Republic

2 Department of Chemistry and Biochemistry, and ${ }^{3}$ Department of Animal Nutrition and Forage Production, Faculty of Agronomy, Mendel University of Agriculture and Forestry, Zemedelska 1, CZ-613 00 Brno, Czech Republic

4 Department of Microelectronics, Faculty of Electrical Engineering and Communication, Brno University of Technology, Udolni 53, CZ-602 00 Brno, Czech Republic

5 Department of Natural Drugs, Faculty of Pharmacy, University of Veterinary and Pharmaceutical Sciences, Palackeho 1-3, CZ-612 42 Brno, Czech Republic

* Author to whom correspondence should be addressed; E-mail: kizek@ sci.muni.cz

Received: 31 July 2008; in revised form: 9 September 2008 / Accepted: 11 September 2008 /

Published: 15 September 2008

\begin{abstract}
Chloride ion sensing is important in many fields such as clinical diagnosis, environmental monitoring and industrial applications. We have measured chloride ions at a carbon paste electrode (CPE) and at a CPE modified with solid $\mathrm{AgNO}_{3}$, a solution of $\mathrm{AgNO}_{3}$ and/or solid silver particles. Detection limits $(3 \mathrm{~S} / \mathrm{N})$ for chloride ions were $100 \mu \mathrm{M}$, $100 \mu \mathrm{M}$ and $10 \mu \mathrm{M}$ for solid $\mathrm{AgNO}_{3}$, solution of $\mathrm{AgNO}_{3}$ and/or solid silver particles, respectively. The CPE modified with silver particles is the most sensitive to the presence chloride ions. After that we approached to the miniaturization of the whole electrochemical instrument. Measurements were carried out on miniaturized instrument consisting of a potentiostat with dimensions $35 \times 166 \times 125 \mathrm{~mm}$, screen printed electrodes, a peristaltic pump and a PC with control software. Under the most suitable experimental conditions (Britton-Robinson buffer, $\mathrm{pH} 1.8$ and working electrode potential $550 \mathrm{mV}$ ) we estimated the limit of detection $(3 \mathrm{~S} / \mathrm{N})$ as $500 \mathrm{nM}$.
\end{abstract}

Keywords: Chloride Ions; Silver; Carbon Paste Electrode; Screen Printed Electrode; Voltammetry; Amperometry 


\section{Introduction}

Chloride ions sensing is important in many fields such as clinical diagnosis [1, 2] environmental monitoring [3-5] and various industrial applications [6, 7]. Considering the fact that chloride channels play crucial role in physiological processes it is not surprising that missregulation of chloride ions transport by these channels can cause serious disorders. Cystic fibrosis is a disease in which gene encoding of a protein, called cystic fibrosis transmembrane regulator, and which functions as a chloride channel in epithelial membranes, is mutated and thus its function is altered [8]. Besides the importance of monitoring of chloride ions in patients with this disease, monitoring of chloride ions in the environment is needed. Chloride ions content in concrete plays important role in the quality of reinforced concrete, as these ions induce depassivation of the steel rebars and initiation of the corrosion process leading to degradation of the structure. Chloride ions in concrete come from cement, aggregate materials and water used for creating concrete, or by diffusion of chloride ions from outside of the structure through water pores in the concrete. Determination of chloride ions in materials for concrete is thus necessary $[3,9]$. The content of chloride ions in waters is also monitored well $[10,11]$.

Numerous analytical methods for chloride ions in a variety of samples have been developed, such as ion chromatography [17, 18] near-infrared spectrometry [12] spectroscopy [13] light scattering [14] ionselective electrode method [6, 9, 15, 16] turbidimetric method [17] and flow based methods coupled with different detectors $[9,18,19]$. On the other hand, sensors and biosensors have the advantages of specificity, low cost, ease to use, portability and the ability to furnish continuous real time signals [20-66]. Several sensors or biosensors for selective chloride ions detection have been suggested $[1,3,6,10,15$, 67-71]. The main aim of this paper was to test various carbon paste electrodes for detection of chloride ions. Moreover, we adopted the results obtained to suggest miniaturized device for in situ monitoring of chloride ions.

\section{Material and Methods}

\subsection{Chemicals, material and pH measurements}

Chemicals used were purchased from Sigma Aldrich Chemical Corp. (USA) in ACS purity unless noted otherwise. The stock standard solutions was prepared with ACS water (Sigma-Aldrich, USA) and stored in the dark at $-4{ }^{\circ} \mathrm{C}$. Working standard solutions were prepared daily by dilution of the stock solutions. The $\mathrm{pH}$ value was measured using WTW inoLab Level 3 with terminal Level 3 (Weilheim, Germany), controlled by the personal computer program (MultiLab Pilot; Weilheim, Germany). The pH-electrode (SenTix-H, pH 0-14/3M KCl) was regularly calibrated by set of WTW buffers (Weilheim, Germany).Deionised water underwent demineralization by reverse osmosis using the instruments Aqua Osmotic 02 (Aqua Osmotic, Tisnov, Czech Republic) and then it was subsequently purified using Millipore RG (Millipore Corp., USA, $18 \mathrm{M} \Omega$ ) - MiliQ water. 


\subsection{Voltammetric measurements}

Voltammetric measurements were performed with an AUTOLAB Analyzer (EcoChemie, Netherlands) connected to a VA-Stand 663 (Metrohm, Switzerland), using a standard cell with three electrodes. The working electrode was a carbon paste electrode. The reference electrode was the $\mathrm{Ag} / \mathrm{AgCl} / 3 \mathrm{M} \mathrm{KCl}$ electrode, and a platinum wire was used as the auxiliary electrode. All experiments were carried out at room temperature. For smoothing and moving average baseline correction GPES 4.9 supplied by EcoChemie was employed. Experimental parameters of adsorptive transfer stripping technique (AdTS) coupled with differential pulse voltammetry (DPV) were as follows: step potential 5 $\mathrm{mV}$, amplitude $25 \mathrm{mV}$, initial potential $0.05 \mathrm{~V}$, end potential $1.1 \mathrm{~V}$ (more details are given in the Results and Discussion section). Britton-Robinson buffer consisted of 1:1:1 $0.04 \mathrm{M}$ boric acid $\left(\mathrm{H}_{3} \mathrm{BO}_{3}\right)$, phosphoric acid $\left(\mathrm{H}_{3} \mathrm{PO}_{4}\right)$ and acetic acid $\left(\mathrm{CH}_{3} \mathrm{COOH}\right)$ adjusted with $0.2 \mathrm{M} \mathrm{NaOH}$ to desired $\mathrm{pH}$.

\subsection{Preparation of carbon paste electrode and its modification}

The carbon paste electrode (CPE) was made of $70 \%(140 \mathrm{mg}, w / w)$ graphite powder (SigmaAldrich) and $30 \%(70 \mathrm{mg}, w / w)$ mineral oil (Sigma-Aldrich; free of DNase, RNase, and protease). This carbon paste was housed in a Teflon body with a $2.5-\mathrm{mm}$ diameter disk surface. Before measurements the electrode surface was renewed by wiping with wet filter paper. Then, the surface was ready for measurement of a $5 \mu \mathrm{L}$ sample volume [72-75]. The silver modified-CPE was prepared in the same way as described above, with the exception of adding solution of $\mathrm{AgNO}_{3}$, solid form of $\mathrm{AgNO}_{3}$ or $\mathrm{Ag}$ particles (units of $\mu \mathrm{m}$ ) into graphite powder and mineral oil. This mixture was ground to perfection for $10 \mathrm{~min}$ using agate grinding mortar.

\subsection{Amperometric measurements}

Amperometric measurements were carried out with multi-mode potentiostat BioStat (ESA, Inc. USA). It is four-channel system with three operating modes per channel (amps, volts, and temp). The system was connected through data bus USB to personal computer. The home made apparatus was connected to the first channel of the potentiostat. This apparatus consists of a basic plate on which the connector TX721 1115 with 2.54 pin spacing and the 0039532035 connector (Molex) with $1.25 \mathrm{~mm}$ pin spacing are placed. The connectors are designed for connection of two different screen-printed electrodes. Miniaturised electrode system consisted of working (silver), auxiliary (carbon) and reference $(\mathrm{Ag} / \mathrm{AgCl})$ electrode. Screen-printed electrodes are fabricated using standard thick-film techniques [76] on an alumina substrate forming the three-electrodes electrochemical sensor with dimensions of $25.4 \times 7.2 \mathrm{~mm}$ [27]. Thick-film paste used for leads and contacts was AgPdPt based paste type ESL 9562-G (ESL Electroscience, UK). For auxiliary electrode Pt based paste type ESL 5545 was used. The working electrode was fabricated from Ag based paste type ESL 9912-K. Finally the reference electrode was fabricated from DuPont (DuPont, USA) paste type 5874 (Ag: $\mathrm{AgCl} \mathrm{ratio:}$ $65: 35)$. 


\subsection{Descriptive statistics}

Data were processed using MICROSOFT EXCEL® (USA). Results are expressed as mean \pm S.D. unless noted otherwise. The detection limits (3 S/N) were calculated according to Long and Winefordner [77] whereas $\mathrm{N}$ was expressed as standard deviation of noise determined in the signal domain unless stated otherwise.

\section{Results and Discussion}

\subsection{Carbon paste electrode modified by solid $\mathrm{AgNO}_{3}$}

We measured chloride ions at the carbon paste electrode. The signal obtained was not well developed. The detection limit ( $3 \mathrm{~S} / \mathrm{N}$ ) was estimated down to $10^{-4} \mathrm{M}$. Therefore it was necessary to modify a working electrode (Figure 1). It is a common knowledge that silver (I) ions form a nonsoluble $\mathrm{AgCl}$ precipitate with chloride ions. We used this feature to select suitable CPE modifiers to detect chloride ions. Primarily we choose solid silver (I) nitrate as the modifier (6 mg of $\mathrm{AgNO}_{3}$ was added to CPE).

Figure 1. Chloride ion sensor. Sensor is based on modification of a carbon paste electrode with silver (I). Reaction between silver (I) and chloride ions provides high selectivity and sensitivity for detection of chloride.

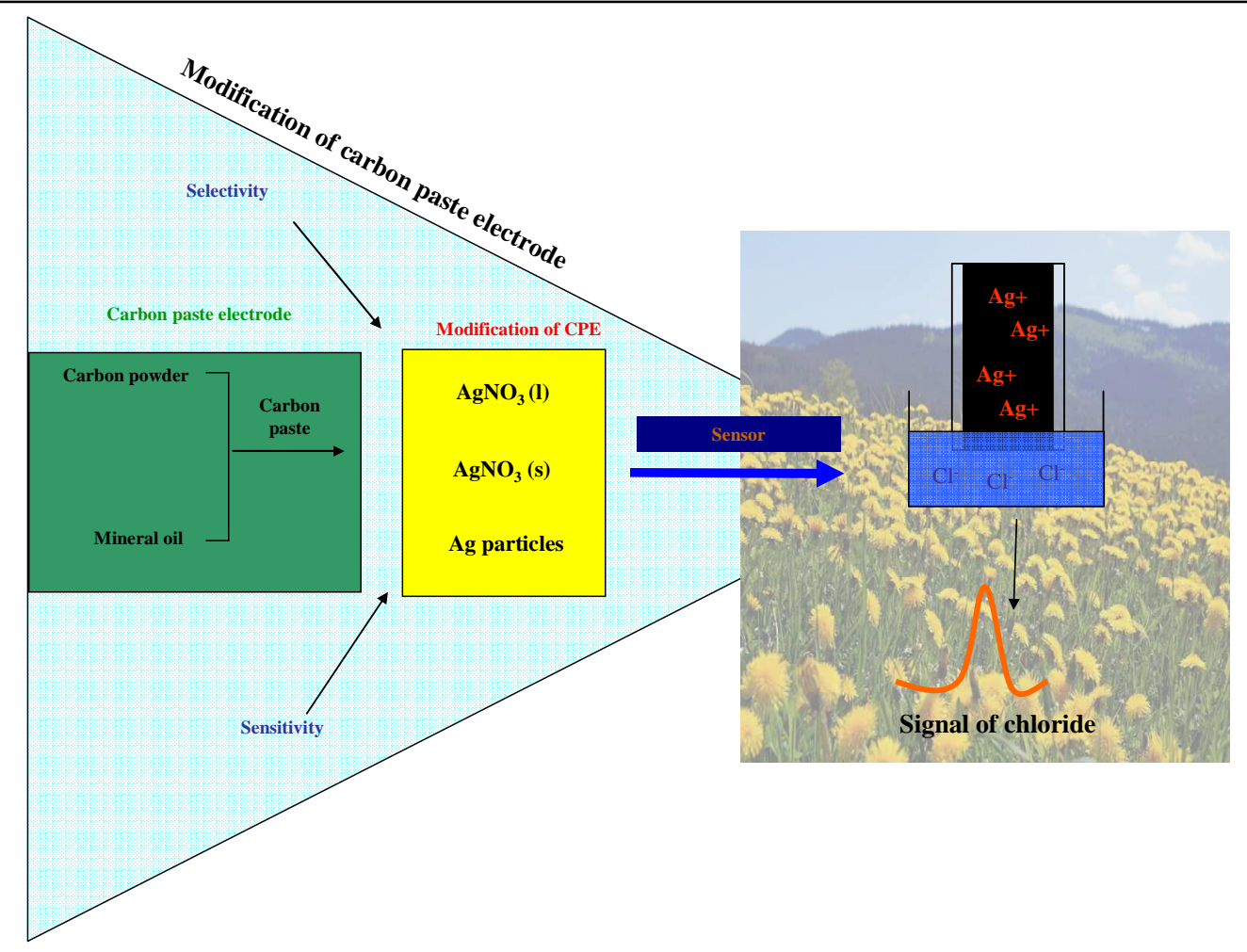


The CPE modified by solid silver (I) nitrate didn't give a signal in the presence of Britton-Robinson buffer ( $\mathrm{pH}$ 1.8) only (not shown). Signal detected using modified CPE probably relates to formation of $\mathrm{AgCl}$ and its dissociation. Chlorides can be also adsorbed on the mercury electrode surface at $+100 \mathrm{mV}$ under formation of products with mercury similarly to silver electrodes surface. It was generally considered that this bond is too strong to be pure sorption. Their common superficial concentration is about $1.5 \mathrm{nmol} / \mathrm{m}^{2}[11,78]$. Therefore we tested the influence of accumulation of $\mathrm{AgCl}$ on the surface of modified CPE. Differential pulse voltammetric analysis was initiated by the accumulation of reaction product at potential $+250 \mathrm{mV}$. The quantity of accumulated product increased with the time of accumulation up to $60 \mathrm{~s}$, and then the signal declined (Figure 2A). The dependence of peak height on $\mathrm{NaCl}$ concentration within the range from $125 \mu \mathrm{M}$ to $1 \mathrm{mM}$ was studied (Figure $2 \mathrm{~B}$ ). The obtained signals were well developed and decreased from $1.2 \mu \mathrm{A}$ to $0.2 \mu \mathrm{A}$ with decreasing concentration of chloride ions. Potential of peak shifted to more positive potentials from 218 to $290 \mathrm{mV}$. Limit of detection $(3 \mathrm{~S} / \mathrm{N})$ was estimated as $100 \mu \mathrm{M} \mathrm{NaCl}$.

Figure 2. Electrochemical analysis of chloride ions using a CPE modified with solid silver(I) nitrate. (A) Dependence of signal height $(100 \mu \mathrm{M} \mathrm{NaCl})$ on accumulation time. Accumulation potential $250 \mathrm{mV}$. (B) DP voltammograms of $\mathrm{NaCl}(0.125,0.250,0.500$ and $1.00 \mathrm{mM})$.

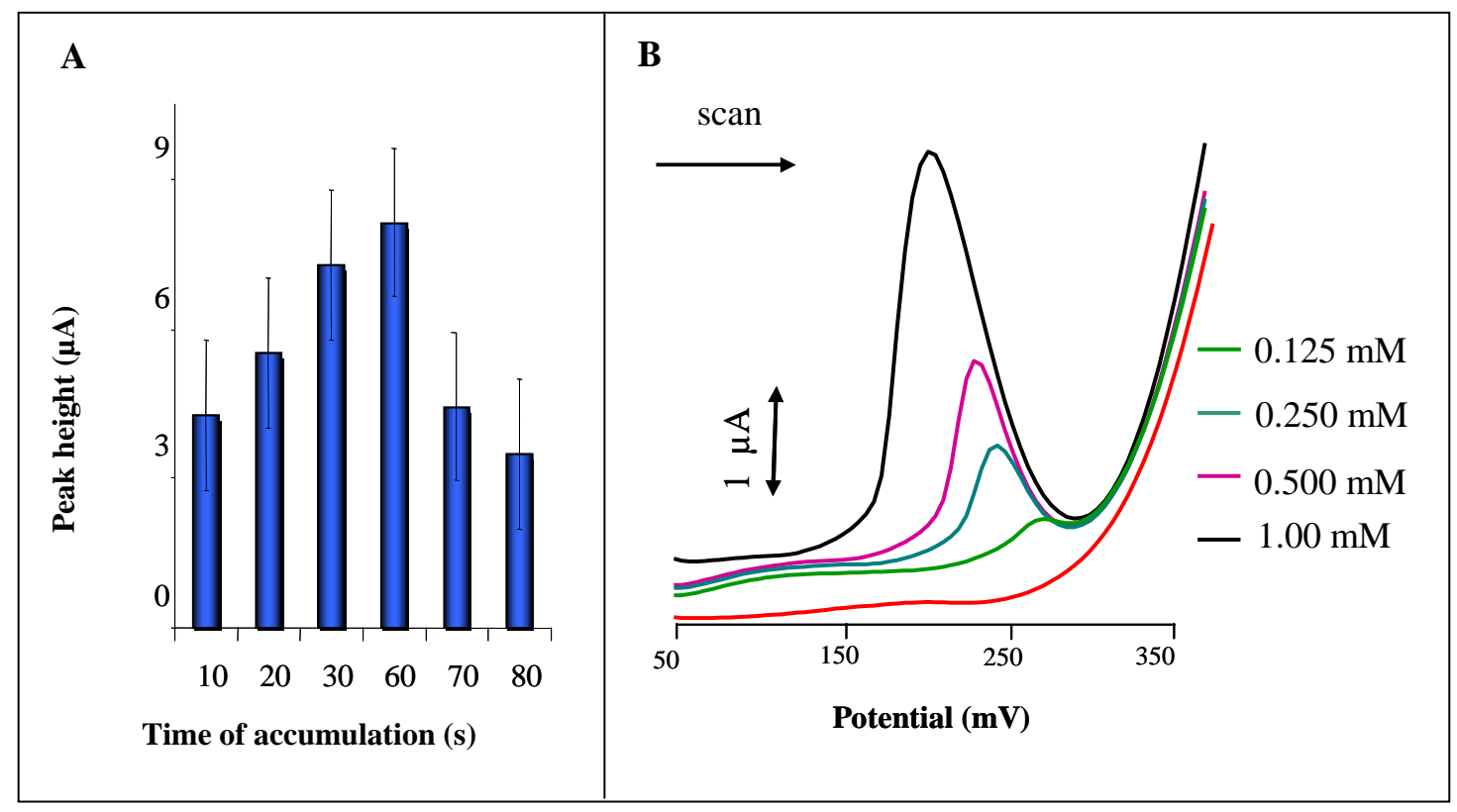

\subsection{Carbon paste electrode modified by solution of $\mathrm{AgNO}_{3}$}

In the following experiments the $\mathrm{CPE}$ was modified by aqueous silver(I) nitrate solution $(0.4 \mu \mathrm{L}$ of solution of $\mathrm{AgNO}_{3} 1 \mathrm{~g} / \mathrm{mL}$ was added to the CPE). The CPE modified like this didn't give a signal in the presence of Britton-Robinson buffer ( $\mathrm{pH}$ 1.8) only. After addition of $1 \mathrm{mM} \mathrm{NaCl}$ into the supporting electrolyte, a peak at $225 \mathrm{mV}$ was determined. We observed that $\mathrm{NaCl}$ concentrations higher than $1 \mathrm{mM}$ resulted in inhomogeneous saturation of modified $\mathrm{CPE}$ electrode surface by $\mathrm{AgCl}$ 
precipitate. This phenomenon caused nonlinearity of calibration curve in the range of the higher $\mathrm{NaCl}$ concentrations. The dependence of peak height on $\mathrm{NaCl}$ concentration within the range from $125 \mu \mathrm{M}$ to $1 \mathrm{mM}$ was linear, which shows on optimal ratio of aqueous silver (I) nitrate solution into CPE and concentration of chloride ions in supporting electrolyte. Therefore it can be also assumed that layer of $\mathrm{AgCl}$ precipitate on the surface of modified $\mathrm{CPE}$ is more homogenous. With increasing $\mathrm{NaCl}$ concentration potential of peak shifted to more positive potentials from $230 \mathrm{mV}$ to $290 \mathrm{mV}$. Limit of detection (3 S/N) was estimated as $100 \mu \mathrm{M} \mathrm{NaCl}$.

Figure 3. Electrochemical analysis of chloride ions using CPE modified by silver microparticles. DP voltammograms of $\mathrm{NaCl}(0.0625,0.125,0.250,0.500$ and $1.00 \mathrm{mM})$.

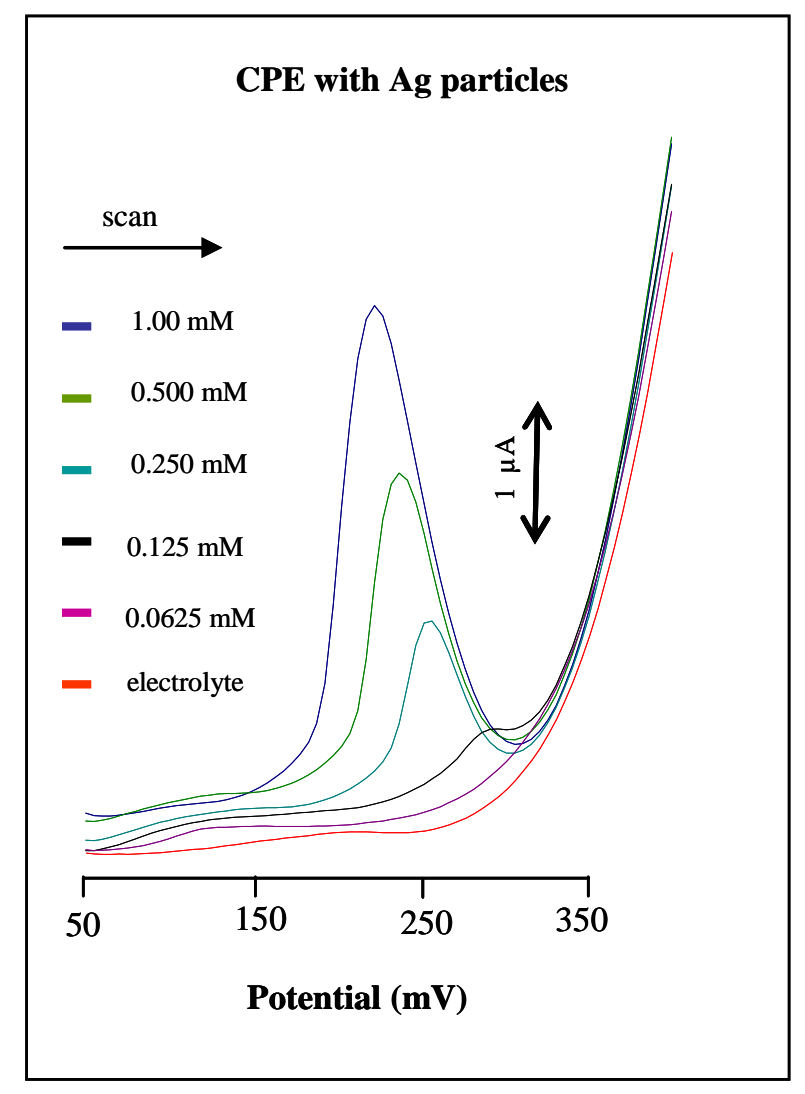

\subsection{Carbon paste electrode modified by silver microparticles}

The CPE modified with silver microparticles (units of $\mu \mathrm{m}$ ) is the most similar to a silver electrode. The additions of silver microparticles from $0.4 \mathrm{mg}$ to $200 \mathrm{mg}$ into carbon powder were tested. Silver microparticles additions below $50 \mathrm{mg}$ didn't provide sufficient sensitivity for chloride ion detection, because the detection limit $(3 \mathrm{~S} / \mathrm{N})$ was higher than $250 \mu \mathrm{M} \mathrm{NaCl}$. Silver microparticles contents higher than $160 \mathrm{mg}$ made the CPE physical conditions worse; particularly a shorter shelf life of the working electrode and lower sensitivity were observed. We determined that the optimal composition of the modified CPE was $140 \mathrm{mg}$ of $\mathrm{Ag}$ particles per $140 \mathrm{mg}$ carbon powder $(1: 1, w / w)$. This rate provided sufficient sensitivity and shelf life longer than four weeks. Chloride ions were measured within the concentration range from $100 \mu \mathrm{M}$ to $1 \mathrm{mM} \mathrm{NaCl}$. DP voltammetric peaks were well 
developed with relative standard deviation below $5 \%$ (Figure 3). Peak height decreased proportionally (from $8 \mu \mathrm{A}$ to $0.2 \mu \mathrm{A}$ ) with decreasing chloride concentration and its potential shifted to more positive potentials (from $230 \mathrm{mV}$ to $290 \mathrm{mV}$ ). Limit of detection $(3 \mathrm{~S} / \mathrm{N}$ ) was estimated as $10 \mu \mathrm{M} \mathrm{NaCl}$. Ten times lower detection limit may relate with larger active surface of silver on the surface of CPE, because silver particle probably homogenously saturated CPE. Considering principle of a measurement stripping of $\mathrm{AgCl}$ on the surface of CPE modified by silver particle can be expected.

It can be concluded that CPE modified by silver particles is the most sensitive to the presence of chloride ions. Therefore we optimized basic experimental conditions and used the CPE modified with silver particles. The type of supporting electrolyte was the first condition to be optimized. The highest current response of chloride ions $(100 \mu \mathrm{M})$ was measured in Britton-Robinson buffer. The height of the chloride peak measured in the presence of acetate and/or borate buffer was for more than $50 \%$ lower compared to Britton-Robinson peak (Figure 4A). The $\mathrm{pH}$ of the supporting electrolyte also influenced the chloride ion signal. Hence, optimization of $\mathrm{pH}$ of Britton-Robinson buffer was our second step. Higher current responses were determined at lower $\mathrm{pH}$ values. Moreover relative standard deviation enhanced with increasing $\mathrm{pH}$ of the buffer from $1.2 \%$ to $4.5 \%(n=5)$. Dependence of chloride ions peak height on its concentration measured in Britton-Robinson buffer ( $\mathrm{pH} 1.8$ ) is shown in Figure 4B. The dependence was strictly linear $\left(\mathrm{y}=0.0011 \mathrm{x}+0.0317, \mathrm{R}^{2}=0.9952\right)$. Due to optimisation steps limit of detection $(3 \mathrm{~S} / \mathrm{N})$ was lowered and estimated as $1 \mu \mathrm{M} \mathrm{NaCl}$.

Figure 4. Electrochemical analysis of chloride ions using CPE modified with silver microparticles. (A) Effect of type of supporting electrolyte (Britton-Robinson, Acetate and Borate buffer) on chloride ions response. (B) Calibration curve.

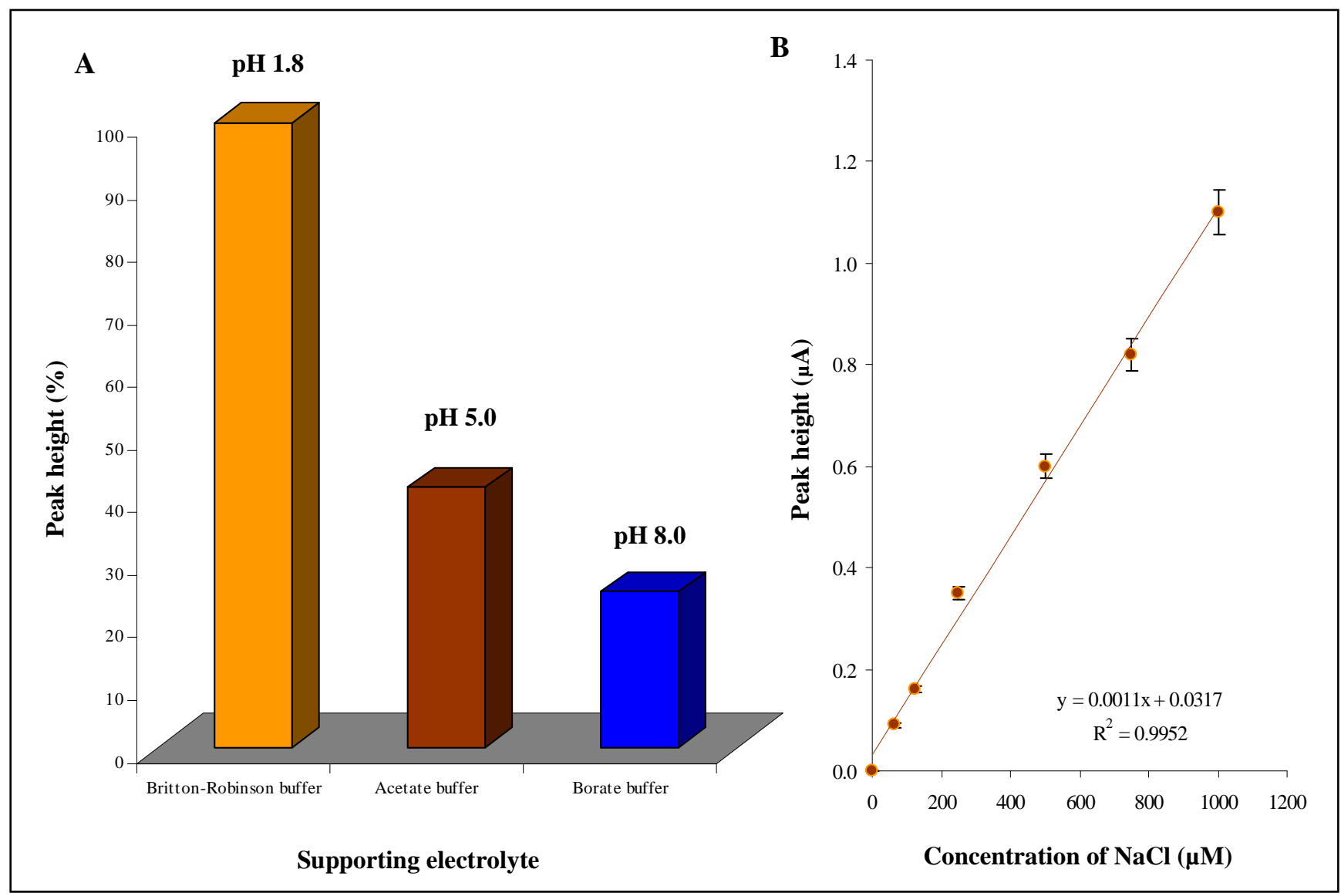




\subsection{Miniaturization of measuring device}

After we successfully optimized the modifications of CPEs which were connected to a standard laboratory potentiostat, we approached the miniaturization of the whole electrochemical instrument. The measurements were carried out on miniaturized instrument consisted of a Biostat potentiostat with dimensions $35 \times 166 \times 125 \mathrm{~mm}$, screen printed electrodes, a peristaltic pump and a PC with control software (Figure 5). The electrochemical flow cell was connected to the peristaltic pump via capillary tubing. The pump introduced the supporting electrolyte and samples. Screen printed electrodes with silver electrode as working one were inserted into the cell. The electrodes were connected to miniaturized potentiostat controlled by PC, where electrochemical responses were recorded. To obtain well repeatable responses full immersing of screen printed electrodes was needed.

Figure 5. Scheme of the miniaturized flow system.

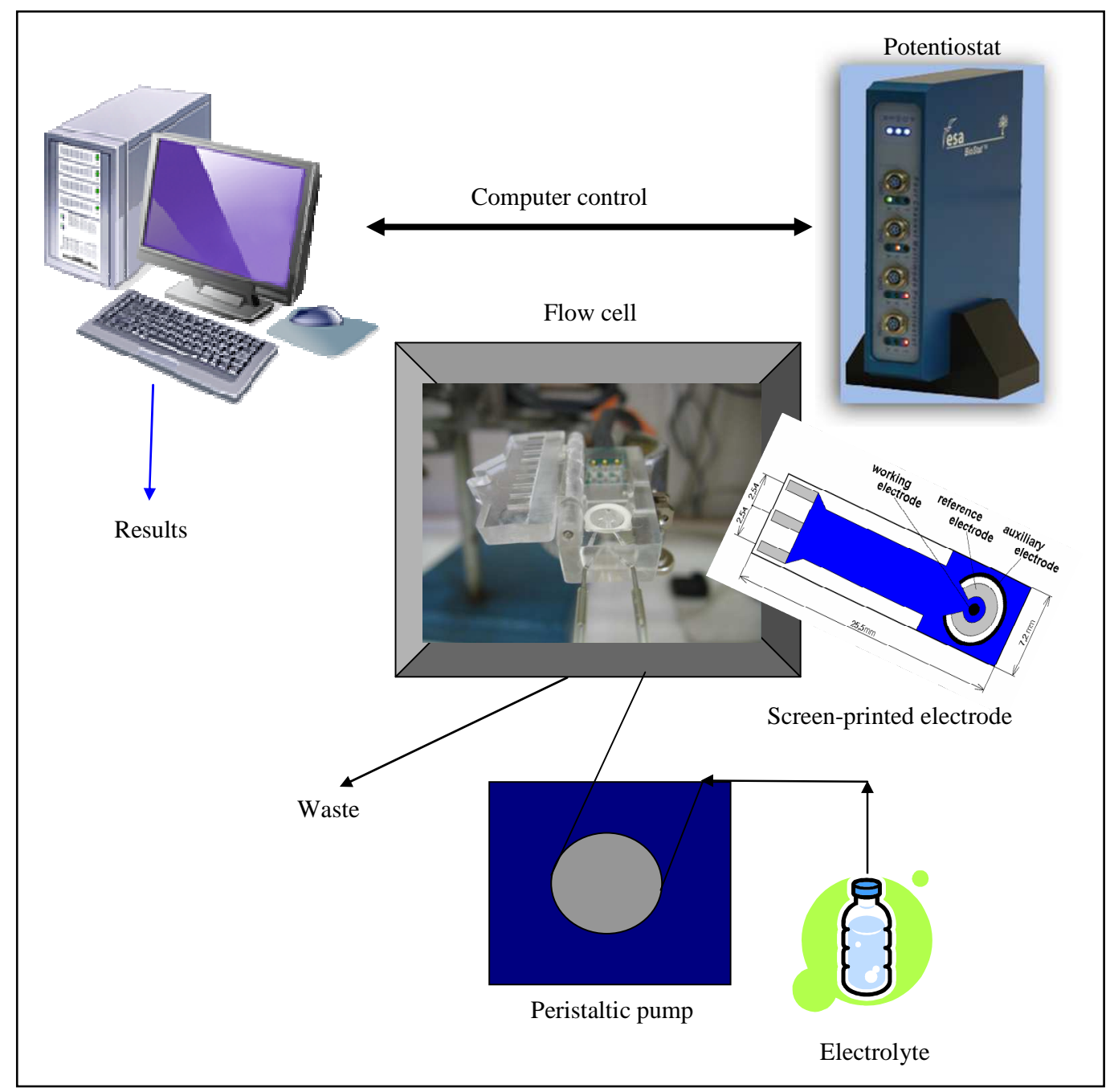

A surface electron microscopic microphotograph of the fabricated Ag-based working electrode surface is shown in Figure 6. Planar screen printed electrodes are intended for one use only, but it is more convenient to utilize them several times for measurements. Therefore we focused on a way to 
recycle the electrodes. The electrode surface was washed with MiliQ water and polished mechanically with alumina between two independent measurements.

Using this cleaning cycle $\mathrm{NaCl}(0.5 \mathrm{mM})$ was detected forty times. The signal decreased with increasing number of measurements. However relative standard deviation was below $11 \%$. These electrodes can be used for more than tens measurements without considerable lost in height of peak of interest. Cost per one analysis of chlorides in sample is thus markedly reduced. In addition new possibilities of proposing of easy to use and low cost instruments for on-line monitoring of environment are opened.

Figure 6. Surface electron microscopic microphotograph of silver working electrode surface (left), in detail (right).

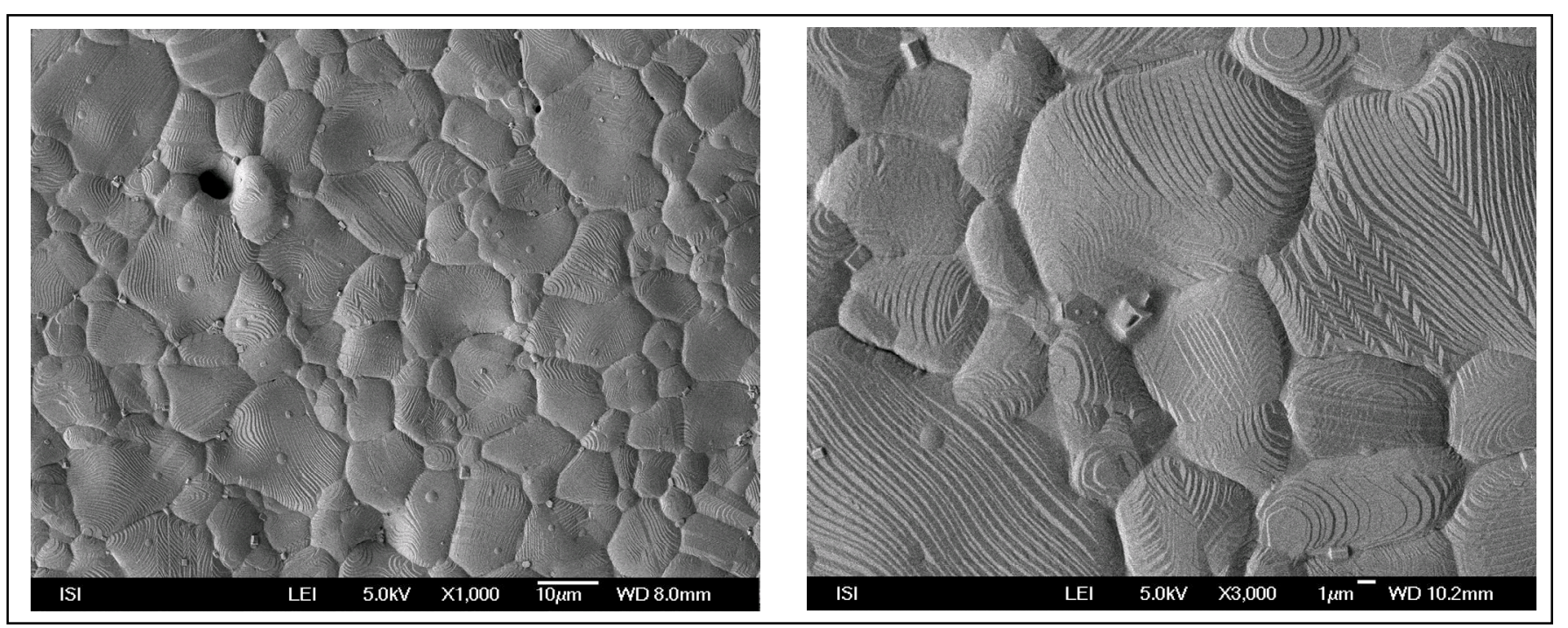

\section{Influence of applied potential and chloride concentrations}

Based on the above mentioned results we choose Britton-Robinson buffer ( $\mathrm{pH}$ 1.8) as supporting electrolyte. It follows from the voltammograms shown in Figures 2 and 3 that the highest current response was detected within the range of potentials from 150 to $250 \mathrm{mV}$. Due to the change in the electrode system we investigated on the influence of applied potential (from 100 to $900 \mathrm{mV}$ ) on chloride ion peak height. The hydrodynamic voltammogram obtained is shown in Figure 7A. Marked enhancement of chloride ions peak was observed from $350 \mathrm{mV}$. The highest peaks were measured at $600 \mathrm{mV}$. Under potentials higher than $650 \mathrm{mV}$, current response decreased (Figure 7A). It clearly follows from the results obtained that the most suitable potential for detection of chloride ions was 600 $\mathrm{mV}$.

Under the most suitable experimental conditions (Britton-Robinson buffer, $\mathrm{pH} 1.8$ and working electrode potential $600 \mathrm{mV}$ ) we studied the effect of different chloride ions concentration on its response. Characteristic amperometric responses are shown in Figure 7B. Before two independent measurements the electrode was polished as mentioned above and, moreover, we had to wait to establish base line. The whole process didn't take more than 5 min. A typical calibration curve is 
shown in Figure 7C. Concentrations higher than $500 \mu \mathrm{M}$ form multilayers on the working electrode surface, which results in a slight decrease in peak height. The calibration curve obtained within the range from 5 to $500 \mu \mathrm{M}$ was strictly linear with the following equation $\mathrm{y}=0.2534 \mathrm{x}+5.011 ; \mathrm{R}^{2}=$ 0.9969 , relative standard deviation $7.5 \%$. The limit of detection $(3 \mathrm{~S} / \mathrm{N})$ was estimated as $500 \mathrm{nM}$ $\mathrm{NaCl}$.

Figure 7. Chloride ion detection using screen printed electrodes. (A) Hydrodynamic voltammogram of chloride ions $(100 \mu \mathrm{M})$. (B) Amperometric signals of chloride ions $(1000,500,250,125,63,32,15$ and $7 \mu \mathrm{M})$. (C) Calibration curve.

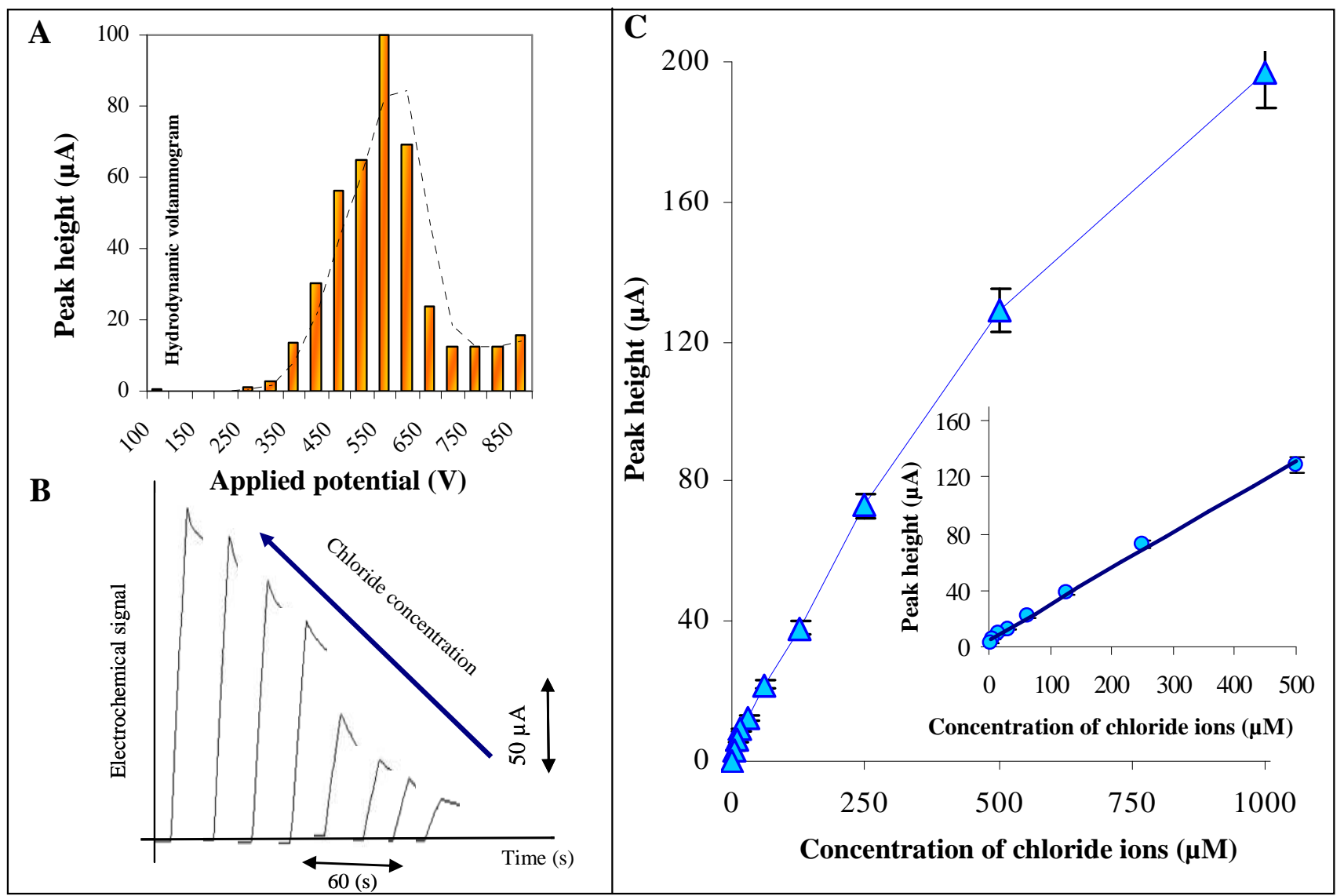

\section{Conclusions}

From the electrodes used for detection of chloride ions screen printed ones connected to miniaturized potentiostat is the most sensitive. This instrument also represents easy-to-use and well portable device for monitoring of chloride ions concentration in various types of samples. Environment is polluted with many toxic compounds contained chloride ions such as persistent organic pollutants (POPs), detergents, and other chemicals.

POPs are chemical substances that persist in the environment, bioaccumulate through the food web, and pose a risk of causing adverse effects to human health and the environment. In light of evidence of long-range transport of these substances to regions where they have never been used or produced, several international communities and organizations have called for urgent global actions to reduce and 
eliminate releasing of these chemicals. Their cycle in environment is well established. In the latter half of the $20^{\text {th }}$ century these compounds presented considerable technological progress. One of the most "famous" POP molecules is DDT (Dichloro-Diphenyl-Trichloroethane), a general-purpose insecticide toxic to most insect pests. DDT was used with great effect to control mosquitoes responsible for spreading malaria, typhus, and other insect-borne diseases among populations. Nevertheless, after long-lasting exposition it has been demonstrated that POPs may cause may cause cancer and that their agricultural use was a threat to wildlife, particularly birds. Based on these findings usage of POPs has been banned in most of all countries on the world [79-85]. Nowadays, POPs still persist in planetary cycle with continuing entries from various sources (Figure 8).

Figure 8. Schematic of the POP cycle in the environment. POPs are released from local sources and transported via atmosphere. They enter locally into water ecosystems (particularly plankton); plankton is subsequently consumed by fish. Predators including humans are also affected because they stand in the top of food chain. The second way is surface contamination of plants.

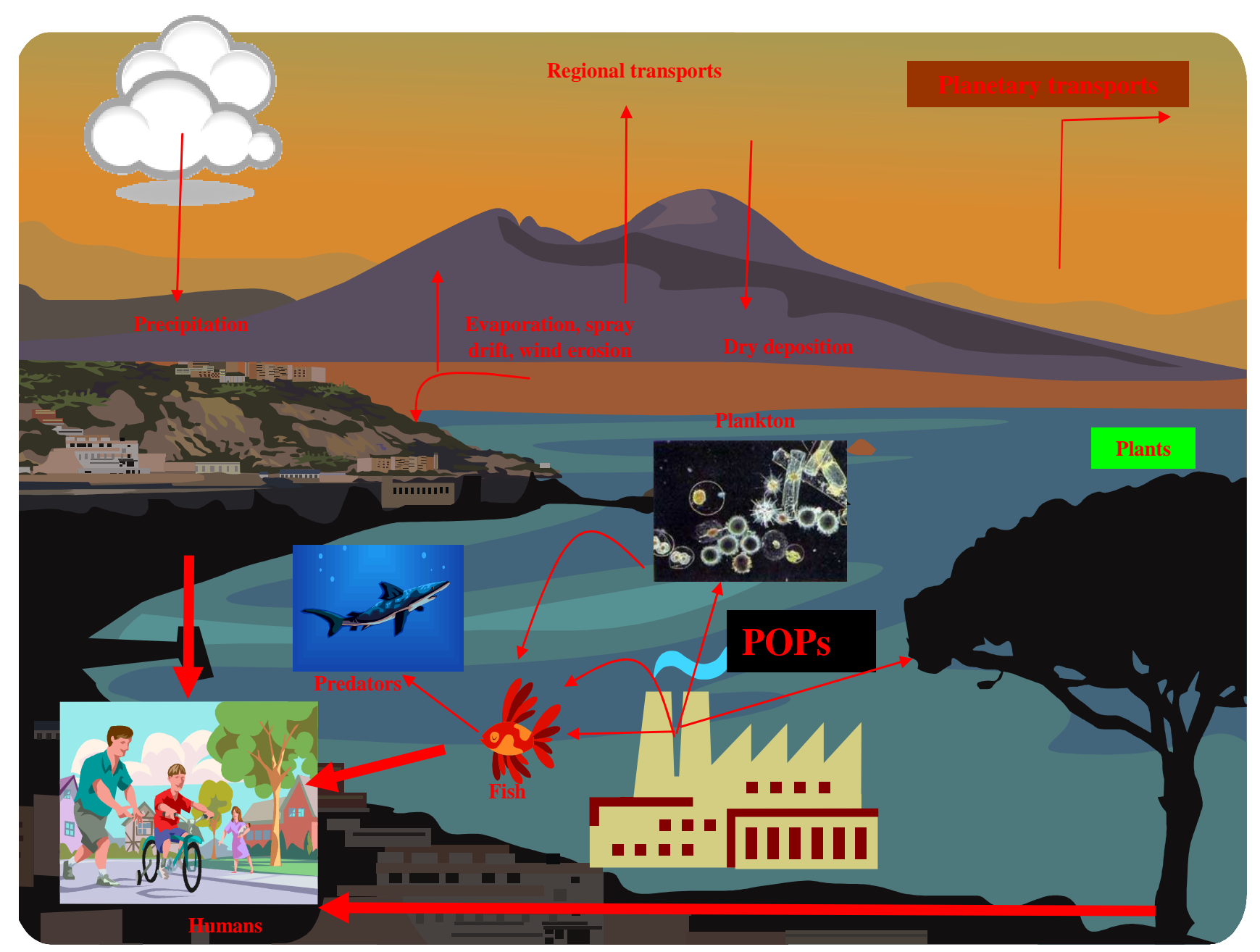


Recently, it was published that enzymatic cleavage of these POPs into the corresponding hydrocarbon and halide can be successfully utilized for indirect detection of these toxic compounds [30]. The enzymes used for this purposes are involved in biochemical pathways enabling bacteria to utilize halogenated compounds via releasing halogen ion from the molecule of halogenated hydrocarbon [86-92]. A scheme of a biosensor using dehalogenase and our miniaturized instrument is shown in Figure 9.

Figure 9. Suggestion of enzyme biosensor for analysis of POPs. Pollutant is introduced on the biosensor, where enzymatic cleavage of the pollutant takes place. Hydrocarbon and chloride are released during reaction. Released chloride is detected.

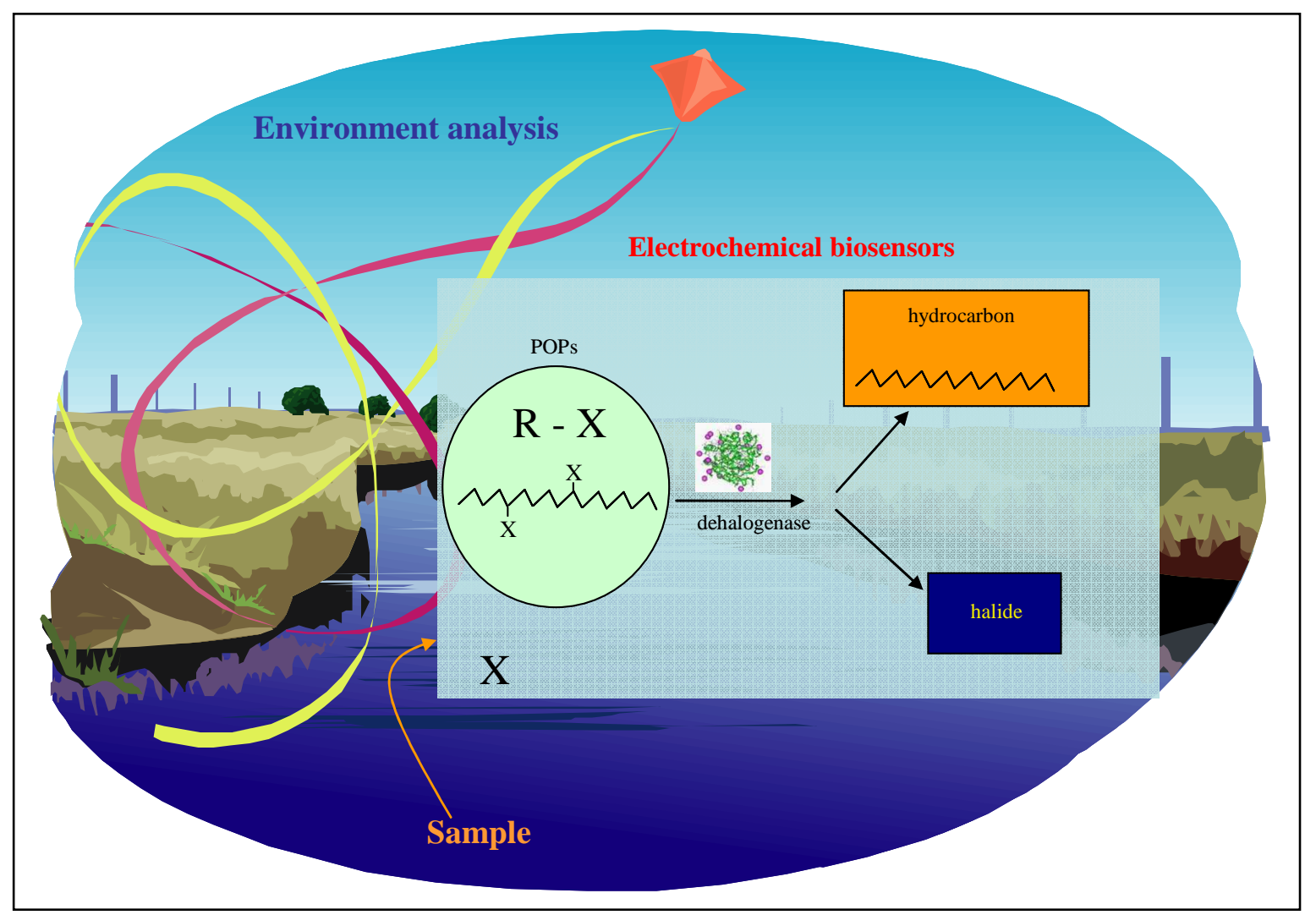

\section{Acknowledgements}

Financial support from MSMT INCHEMBIOL 0021622412 is greatly acknowledged. The authors wish to express their thanks to Jan Hradecky for excellent technical assistance.

\section{References}

1. Jiang, Q.S.; Mak, D.; Devidas, S.; Schwiebert, E.M.; Bragin, A.; Zhang, Y.L.; Skach, W.R.; Guggino, W.B.; Foskett, J.K.; Engelhardt, J.F. Cystic fibrosis transmembrane conductance regulator-associated ATP release is controlled by a chloride sensor. J. Cell Biol. 1998, 143, 645-657. 
2. Huber, C.; Werner, T.; Krause, C.; Klimant, I.; Wolfbeis, O.S. Energy transfer-based lifetime sensing of chloride using a luminescent transition metal complex. Anal. Chim. Acta 1998, 364, 143-151.

3. Montemor, M.F.; Alves, J.H.; Simoes, A.M.; Fernandes, J.C.S.; Lourenco, Z.; Costa, A.J.S.; Appleton, A.J.; Ferreira, M.G.S. Multiprobe chloride sensor for in situ monitoring of reinforced concrete structures. Cem. Concr. Compos. 2006, 28, 233-236.

4. Huber, C.; Klimant, I.; Krause, C.; Werner, T.; Mayr, T.; Wolfbeis, O.S. Optical sensor for seawater salinity. Fresenius J. Anal. Chem. 2000, 368, 196-202.

5. Martin, A.; Narayanaswamy, R. Studies on quenching of fluorescence of reagents in aqueous solution leading to an optical chloride-ion sensor. Sens. Actuator B-Chem. 1997, 39, 330-333.

6. Babu, J.N.; Bhalla, V.; Kumar, M.; Mahajan, R.K.; Puri, R.K. A chloride selective sensor based on a calix[4]arene possessing a urea moiety. Tetrahedron Lett. 2008, 49, 2772-2775.

7. Badr, I.H.A.; Diaz, M.; Hawthorne, M.F.; Bachas, L.G. Mercuracarborand "anti-crown ether"based chloride sensitive liquid/polymeric membrane electrodes. Anal. Chem. 1999, 71, 1371-1377.

8. Ratjen, F.; Doring, G. Cystic fibrosis. Lancet 2003, 361, 681-689.

9. Junsomboon, J.; Jakmunee, J. Determination of chloride in admixtures and aggregates for cement by a simple flow injection potentiometric system. Talanta 2008, 76, 365-368.

10. Hahn, F. Novel valve for automatic calibration of a chloride sensor for river monitoring. Biosyst. Eng. 2005, 92, 275-284.

11. Sebkova, S. Determination of chlorides on composite silver electrodes. Chem. Listy 2003, 97, 201-205.

12. Wu, R.H.; Shao, X.G. Application of near-infrared spectra in the determination of water soluble chloride ion in plant samples. Spectrosc. Spectr. Anal. 2006, 26, 617-619.

13. Philippi, M.; dos Santos, H.S.; Martins, A.O.; Azevedo, C.M.N.; Pires, M. Alternative spectrophotometric method for standardization of chlorite aqueous solutions. Anal. Chim. Acta 2007, 585, 361-365.

14. Cao, H.; Dong, H.W. Rapid and sensitive determination of trace chloride ion in drinks using resonance light scattering technique. J. Autom. Methods Manag. Chem. 2008, Article Number $745636,5$.

15. Kumar, K.G.; John, K.S.; Indira, C.J. A chloride ion-selective potentiometric sensor based on a polymeric schiff base complex. Indian J. Chem. Technol. 2006, 13, 13-16.

16. Shishkanova, T.V.; Sykora, D.; Sessler, J.L.; Kral, V. Potentiometric response and mechanism of anionic recognition of heterocalixarene-based ion selective electrodes. Anal. Chim. Acta 2007, 587, 247-253.

17. Mesquita, R.B.R.; Fernandes, S.M.V.; Rangel, A. Turbidimetric determination of chloride in different types of water using a single sequential injection analysis system. J. Environ. Monit. 2002, 4, 458-461.

18. Pimenta, A.M.; Araujo, A.N.; Conceicao, M.; Montenegro, B.S.M.; Pasquini, C.; Rohwedder, J.J.R.; Raimundo, I.M. Chloride-selective membrane electrodes and optodes based on an indium(III) porphyrin for the determination of chloride in a sequential injection analysis system. $J$. Pharm. Biomed. Anal. 2004, 36, 49-55. 
19. Bonifacio, V.G.; Figueiredo-Filho, L.C.; Marcolino, L.H.; Fatibello-Filho, O. An improved flow system for chloride determination in natural waters exploiting solid-phase reactor and long pathlength spectrophotometry. Talanta 2007, 72, 663-667.

20. Krizkova, S.; Ryant, P.; Krystofova, O.; Adam, V.; Galiova, M.; Beklova, M.; Babula, P.; Kaiser, J.; Novotny, K.; Novotny, J.; Liska, M.; Malina, R.; Zehnalek, J.; Hubalek, J.; Havel, L.; Kizek, R. Multi-instrumental analysis of tissues of sunflower plants treated with silver(I) ions - Plants as bioindicators of environmental pollution. Sensors 2008, 8, 445-463.

21. Adam, V.; Zitka, O.; Dolezal, P.; Zeman, L.; Horna, A.; Hubalek, J.; Sileny, J.; Krizkova, S.; Trnkova, L.; Kizek, R. Lactoferrin isolation using monolithic column coupled with spectrometric or micro-amperometric detector. Sensors 2008, 8, 464-487.

22. Adam, V.; Mikelova, R.; Hubalek, J.; Hanustiak, P.; Beklova, M.; Hodek, P.; Horna, A.; Trnkova, L.; Stiborova, M.; Zeman, L.; Kizek, R. Utilizing of square wave voltammetry to detect flavonoids in the presence of human urine. Sensors 2007, 7, 2402-2418.

23. Hubalek, J.; Hradecky, J.; Adam, V.; Krystofova, O.; Huska, D.; Masarik, M.; Trnkova, L.; Horna, A.; Klosova, K.; Adamek, M.; Zehnalek, J.; Kizek, R. Spectrometric and voltammetric analysis of urease - nickel nanoelectrode as an electrochemical sensor. Sensors 2007, 7, 1238-1255.

24. Zitka, O.; Huska, D.; Krizkova, S.; Adam, V.; Chavis, G.J.; Trnkova, L.; Horna, A.; Hubalek, J.; Kizek, R. An investigation of glutathione-platinum(II) interactions by means of the flow injection analysis using glassy carbon electrode. Sensors 2007, 7, 1256-1270.

25. Vitecek, J.; Petrlova, J.; Adam, V.; Havel, L.; Kramer, K.J.; Babula, P.; Kizek, R. A fluorimetric sensor for detection of one living cell. Sensors 2007, 7, 222-238.

26. Supalkova, V.; Petrek, J.; Havel, L.; Krizkova, S.; Petrlova, J.; Adam, V.; Potesil, D.; Babula, P.; Beklova, M.; Horna, A.; Kizek, R. Electrochemical sensors for detection of acetylsalicylic acid. Sensors 2006, 6, 1483-1497.

27. Prasek, J.; Adamek, M.; Hubalek, J.; Adam, V.; Trnkova, L.; Kizek, R. New hydrodynamic electrochemical arrangement for cadmium ions detection using thick-film chemical sensor electrodes. Sensors 2006, 6, 1498-1512.

28. Trnkova, L.; Jelen, F.; Petrlova, J.; Adam, V.; Potesil, D.; Kizek, R. Elimination voltammetry with linear scan as a new detection method for DNA sensors. Sensors 2005, 5, 448-464.

29. Adam, V.; Zehnalek, J.; Petrlova, J.; Potesil, D.; Sures, B.; Trnkova, L.; Jelen, F.; Vitecek, J.; Kizek, R. Phytochelatin modified electrode surface as a sensitive heavy-metal ion biosensor. Sensors 2005, 5, 70-84.

30. Mikelova, R.; Prokop, Z.; Stejskal, K.; Adam, V.; Beklova, M.; Trnkova, L.; Kulichova, B.; Horna, A.; Chaloupkova, R.; Damborsky, J.; Kizek, R. Enzymatic reaction coupled with flowinjection analysis with charged aerosol, coulometric, or amperometric detection for estimation of contamination of the environment by pesticides. Chromatographia 2008, 67, S47-S53.

31. Huska, D.; Krizkova, S.; Adam, V.; Hubalek, J.; Trnkova, L.; Prusa, R.; Havel, L.; Kizek, R. Paramagnetic beads coupled with electrochemical detection as a tool to investigate transcriptome.

Tumor Biol. 2007, 28, 124-124. 
32. Petrlova, J.; Krizkova, S.; Zitka, O.; Hubalek, J.; Prusa, R.; Adam, V.; Wang, J.; Beklova, M.; Sures, B.; Kizek, R. Utilizing a chronopotentiometric sensor technique for metallothionein determination in fish tissues and their host parasites. Sens. Actuator B-Chem. 2007, 127, 112-119.

33. Adam, V.; Hanustiak, P.; Krizkova, S.; Beklova, M.; Zehnalek, J.; Trnkova, L.; Horna, A.; Sures, B.; Kizek, R. Palladium biosensor. Electroanalysis 2007, 19, 1909-1914.

34. Kukacka, J.; Krizkova, S.; Zitka, O.; Prusa, R.; Adam, V.; Sures, B.; Beklova, M.; Kizek, R. Study of nucleic acids interactions with platinum based cytostatics using biosensor. Faseb J. 2007, 21, A262-A262.

35. Huska, D.; Zitka, O.; Adam, V.; Beklova, M.; Krizkova, S.; Zeman, L.; Horna, A.; Havel, L.; Zehnalek, J.; Kizek, R. A sensor for investigating the interaction between biologically important heavy metals and glutathione. Czech J. Anim. Sci. 2007, 52, 37-43.

36. Krizkova, S.; Adam, V.; Petrlova, J.; Zitka, O.; Stejskal, K.; Zehnalek, J.; Sures, B.; Trnkova, L.; Beklova, M.; Kizek, R. A suggestion of electrochemical biosensor for study of platinum(II)-DNA interactions. Electroanalysis 2007, 19, 331-338.

37. Adam, V.; Krizkova, S.; Zitka, O.; Trnkova, L.; Petrlova, J.; Beklova, M.; Kizek, R. Determination of apo-metallothionein using adsorptive transfer stripping technique in connection with differential pulse voltammetry. Electroanalysis 2007, 19, 339-347.

38. Vitecek, J.; Petrlova, J.; Petrek, J.; Adam, V.; Potesil, D.; Havel, L.; Mikelova, R.; Trnkova, L.; Kizek, R. Electrochemical study of S-nitrosoglutathione and nitric oxide by carbon fibre NO sensor and cyclic voltammetry - possible way of monitoring of nitric oxide. Electrochim. Acta 2006, 51, 5087-5094.

39. Petrlova, J.; Potesil, D.; Zehnalek, J.; Sures, B.; Adam, V.; Trnkova, L.; Kizek, R. Cisplatin electrochemical biosensor. Electrochim. Acta 2006, 51, 5169-5173.

40. Potesil, D.; Mikelova, R.; Adam, V.; Kizek, R.; Prusa, R. Change of the protein p53 electrochemical signal according to its structural form - Quick and sensitive distinguishing of native, denatured, and aggregated form of the "guardian of the genome". Protein J. 2006, 25, 2332.

41. Adam, V.; Petrlova, J.; Potesil, D.; Zehnalek, J.; Sures, B.; Trnkova, L.; Jelen, F.; Kizek, R. Study of metallothionein modified electrode surface behavior in the presence of heavy metal ionsbiosensor. Electroanalysis 2005, 17, 1649-1657.

42. Prusa, R.; Potesil, D.; Masarik, M.; Adam, V.; Kizek, R.; Jelen, F. Fast and sensitive electrochemical detection of native, denatured, and aggregated forms of tumor suppressor protein p53. Mol. Biol. Cell 2004, 15, 249A-249A.

43. Palecek, E.; Kizek, R.; Havran, L.; Billova, S.; Fojta, M. Electrochemical enzyme-linked immunoassay in a DNA hybridization sensor. Anal. Chim. Acta 2002, 469, 73-83.

44. Kizek, R.; Havran, L.; Fojta, M.; Palecek, E. Determination of nanogram quantities of osmiumlabeled single stranded DNA by differential pulse stripping voltammetry. Bioelectrochemistry 2002, 55, 119-121.

45. Kizek, R.; Trnkova, L.; Sevcikova, S.; Smarda, J.; Jelen, F. Silver electrode as a sensor for determination of zinc in cell cultivation medium. Anal. Biochem. 2002, 301, 8-13. 
46. deSilva, A.P.; Gunaratne, H.Q.N.; Gunnlaugsson, T.; Huxley, A.J.M.; McCoy, C.P.; Rademacher, J.T.; Rice, T.E. Signaling recognition events with fluorescent sensors and switches. Chem. Rev. 1997, 97, 1515-1566.

47. Kong, J.; Franklin, N.R.; Zhou, C.W.; Chapline, M.G.; Peng, S.; Cho, K.J.; Dai, H.J. Nanotube molecular wires as chemical sensors. Science 2000, 287, 622-625.

48. Homola, J.; Yee, S.S.; Gauglitz, G. Surface plasmon resonance sensors: review. Sens. Actuator BChem. 1999, 54, 3-15.

49. Wang, J.; Musameh, M.; Lin, Y.H. Solubilization of carbon nanotubes by Nafion toward the preparation of amperometric biosensors. J. Am. Chem. Soc. 2003, 125, 2408-2409.

50. Wang, J. From DNA biosensors to gene chips. Nucleic Acids Res. 2000, 28, 3011-3016.

51. Wang, J.; Musameh, M. Carbon nanotube/teflon composite electrochemical sensors and biosensors. Anal. Chem. 2003, 75, 2075-2079.

52. Wang, J. Carbon-nanotube based electrochemical biosensors: A review. Electroanalysis 2005, 17, 7-14.

53. Palecek, E.; Fojta, M.; Tomschik, M.; Wang, J. Electrochemical biosensors for DNA hybridization and DNA damage. Biosens. Bioelectron. 1998, 13, 621-628.

54. Wang, J.; Palecek, E.; Nielsen, P.E.; Rivas, G.; Cai, X.H.; Shiraishi, H.; Dontha, N.; Luo, D.B.; Farias, P.A.M. Peptide nucleic acid probes for sequence-specific DNA biosensors. J. Am. Chem. Soc. 1996, 118, 7667-7670.

55. Raiteri, R.; Grattarola, M.; Butt, H.J.; Skladal, P. Micromechanical cantilever-based biosensors. Sens. Actuator B-Chem. 2001, 79, 115-126.

56. Wang, Y.; Xu, H.; Zhang, J.M.; Li, G. Electrochemical sensors for clinic analysis. Sensors 2008, 8, 2043-2081.

57. O'Toole, M.; Diamond, D. Absorbance based light emitting diode optical sensors and sensing devices. Sensors 2008, 8, 2453-2479.

58. Michikawa, Y.; Suga, T.; Ohtsuka, Y.; Matsumoto, I.; Ishikawa, A.; Ishikawa, K.; Iwakawa, M.; Imai, T. Visible genotype sensor array. Sensors 2008, 8, 2722-2735.

59. Belluzo, M.S.; Ribone, M.E.; Lagier, C.M. Assembling amperometric biosensors for clinical diagnostics. Sensors 2008, 8, 1366-1399.

60. Grieshaber, D.; MacKenzie, R.; Voros, J.; Reimhult, E. Electrochemical biosensors - Sensor principles and architectures. Sensors 2008, 8, 1400-1458.

61. Bacci, M.; Cucci, C.; Mencaglia, A.A.; Mignani, A.G. Innovative sensors for environmental monitoring in museums. Sensors 2008, 8, 1984-2005.

62. Rahman, M.A.; Kumar, P.; Park, D.S.; Shim, Y.B. Electrochemical sensors based on organic conjugated polymers. Sensors 2008, 8, 118-141.

63. Bosch, M.E.; Sanchez, A.J.R.; Rojas, F.S.; Ojeda, C.B. Recent development in optical fiber biosensors. Sensors 2007, 7, 797-859.

64. Jaffrezic-Renault, N.; Martelet, C.; Chevolot, Y.; Cloarec, J.P. Biosensors and bio-bar code assays based on biofunctionalized magnetic microbeads. Sensors 2007, 7, 589-614.

65. Schneider, H.J.; Kato, K.; Strongin, R.M. Chemomechanical polymers as sensors and actuators for biological and medicinal applications. Sensors 2007, 7, 1578-1611. 
66. Bai, H.; Shi, G.Q. Gas sensors based on conducting polymers. Sensors 2007, 7, 267-307.

67. Kocherginsky, N.M.; Wang, Z. Polyaniline membrane based potentiometric sensor for ascorbic acid, other redox active species and chloride. J. Electroanal. Chem. 2007, 611, 162-168.

68. Schazmann, B.; Alhashimy, N.; Diamond, D. Chloride selective calix[4]arene optical sensor combining urea functionality with pyrene excimer transduction. J. Am. Chem. Soc. 2006, 128, 8607-8614.

69. Sundaram, R.; Hariprasad, K.S. Synthesis of chloride ion-selective potentiometric sensor based on coordination polymer complex. Indian J. Chem. Technol. 2007, 14, 451-458.

70. Xu, C.; Qin, Y.; Bakker, E. Optical chloride sensor based on [9]mercuracarborand-3 with massively expanded measuring range. Talanta 2004, 63, 180-184.

71. Zhang, W.; Rozniecka, E.; Malinowska, E.; Parzuchowski, P.; Meyerhoff, M.E. Optical chloride sensor based on dimer-monomer equilibrium of indium(III) octaethylporphyrin in polymeric film. Anal. Chem. 2002, 74, 4548-4557.

72. Krizkova, S.; Hrdinova, V.; Adam, V.; Burgess, E.P.J.; Kramer, K.J.; Masarik, M.; Kizek, R. Chip-based CE for avidin determination in transgenic tobacco and its comparison with squarewave voltammetry and standard gel electrophoresis. Chromatographia 2008, 67, S75-S81.

73. Petrlova, J.; Krizkova, S.; Supalkova, V.; Masarik, M.; Adam, V.; Havel, L.; Kramer, K.J.; Kizek, $\mathrm{R}$. The determination of avidin in genetically modified maize by voltammetric techniques. Plant Soil Environ. 2007, 53, 345-349.

74. Kizek, R.; Masarik, M.; Kramer, K.J.; Potesil, D.; Bailey, M.; Howard, J.A.; Klejdus, B.; Mikelova, R.; Adam, V.; Trnkova, L.; Jelen, F. An analysis of avidin, biotin and their interaction at attomole levels by voltammetric and chromatographic techniques. Anal. Bioanal. Chem. 2005, 381, 1167-1178.

75. Masarik, M.; Kizek, R.; Kramer, K.J.; Billova, S.; Brazdova, M.; Vacek, J.; Bailey, M.; Jelen, F.; Howard, J.A. Application of avidin-biotin technology and adsorptive transfer stripping squarewave voltammetry for detection of DNA hybridization and avidin in transgenic avidin maize. Anal. Chem. 2003, 75, 2663-2669.

76. White, N.M.; Turner, J.D. Thick-film sensors: Past, present and future. Meas. Sci. Technol. 1997, $8,1-20$.

77. Long, G.L.; Winefordner, J.D. Limit of Detection. Anal. Chem. 1983, 55, A712-A724.

78. Sebkova, S.; Navratil, T.; Kopanica, M. Silver composite electrode for voltammetric determination of halogenides. Anal. Lett. 2004, 37, 603-628.

79. Carvalho, F.P. Agriculture, pesticides, food security and food safety. Environ. Sci. Policy 2006, 9 , 685-692.

80. Fidalgo-Used, N.; Blanco-Gonzalez, E.; Sanz-Medel, A. Sample handling strategies for the determination of persistent trace organic contaminants from biota samples. Anal. Chim. Acta 2007, 590, 1-16.

81. Godduhn, A.; Duffy, L.K. Multi-generation health risks of persistent organic pollution in the far north: use of the precautionary approach in the Stockholm Convention. Environ. Sci. Policy 2003, 6, 341-353. 
82. Horak, J. Dioxins as a source of hazard for the environment and health. Chem. Listy 2002, 96, 863-868.

83. Lohmann, R.; Breivik, K.; Dachs, J.; Muir, D. Global fate of POPs: Current and future research directions. Environ. Pollut. 2007, 150, 150-165.

84. Muir, D.; Sverko, E. Analytical methods for PCBs and organochlorine pesticides in environmental monitoring and surveillance: a critical appraisal. Anal. Bioanal. Chem. 2006, 386, 769-789.

85. Muir, D.C.G.; Howard, P.H. Are there other persistent organic pollutants? A challenge for environmental chemists. Environ. Sci. Technol. 2006, 40, 7157-7166.

86. Oakley, A.J.; Klvana, M.; Otyepka, M.; Nagata, Y.; Wilce, M.C.J.; Damborsky, J. Crystal structure of haloalkane dehalogenase LinB from Sphingomonas paucimobilis UT26 at 0.95 angstrom resolution: Dynamics of catalytic residues. Biochemistry 2004, 43, 870-878.

87. Chaloupkova, R.; Sykorova, J.; Prokop, Z.; Jesenska, A.; Monincovaa, M.; Pavlova, M.; Tsuda, M.; Nagata, Y.; Damborsky, J. Modification of activity and specificity of haloalkane dehalogenase from Sphingomonas paucimobilis UT26 by engineering of its entrance tunnel. J. Biol. Chem. 2003, 278, 52622-52628.

88. Streltsov, V.A.; Prokop, Z.; Damborsky, J.; Nagata, Y.; Oakley, A.; Wilce, M.C.J. Haloalkane dehalogenase LinB from Sphingomonas paucimobilis UT26: X-ray crystallographic studies of dehalogenation of brominated substrates (vol 42, pg 10104, 2003). Biochemistry 2003, 42, 1271912720.

89. Prokop, Z.; Monincova, M.; Chaloupkova, R.; Klvana, M.; Nagata, Y.; Janssen, D.B.; Damborsky, J. Catalytic mechanism of the haloalkane dehalogenase LinB from Sphingomonas paucimobilis UT26. J. Biol. Chem. 2003, 278, 45094-45100.

90. Bosma, T.; Damborsky, J.; Stucki, G.; Janssen, D.B. Biodegradation of 1,2,3-trichloropropane through directed evolution and heterologous expression of a haloalkane dehalogenase gene. Appl. Environ. Microbiol. 2002, 68, 3582-3587.

91. Nagata, Y.; Mori, K.; Takagi, M.; Murzin, A.G.; Damborsky, J. Identification of protein fold and catalytic residues of gamma-hexachlorocyclohexane dehydrochlorinase LinA. Proteins 2001, 45, 471-477.

92. Damborsky, J.; Rorije, E.; Jesenska, A.; Nagata, Y.; Klopman, G.; Peijnenburg, W. Structurespecificity relationships for haloalkane dehalogenases. Environ. Toxicol. Chem. 2001, 20, 26812689.

(C) 2008 by the authors; licensee Molecular Diversity Preservation International, Basel, Switzerland. This article is an open-access article distributed under the terms and conditions of the Creative Commons Attribution license (http://creativecommons.org/licenses/by/3.0/). 